\title{
Response of Different Sources and Doses of Sulphur on Growth, Yield and Uptake of Onion (Allium cepa L.)
}

\author{
B. R. Nayak ${ }^{1 *}$, P. K. Samanta ${ }^{1}$, N. Panigrahy ${ }^{1}$, S. Mohapatra ${ }^{1}$, A. K. Mohanty ${ }^{1}$, A. K. Dash ${ }^{2}$, B. Jena ${ }^{2}$, N. Panda ${ }^{2}$, \\ B. Sahoo ${ }^{3}$ and P. Mishra ${ }^{4}$ \\ ${ }^{1}$ Regional Research and Technology Transfer Station, OUAT, Chiplima, Sambalpur, Odisha (768 025), India \\ ${ }^{2}$ College of Agriculture, OUAT, Bhubaneswar, Odisha (751 003), India \\ ${ }^{3}$ Krishi Vigyan Kendra, OUAT, Ranital, Bhadrak, Odisha (751 111), India \\ ${ }^{4}$ Krishi Vigyan Kendra, OUAT, Jharsuguda, Odisha (767 002), India
}

\section{Article History}

Manuscript No. AR1502

Received in $28^{\text {th }}$ November, 2015

Received in revised form $28^{\text {th }}$ January, 2016

Accepted in final form $5^{\text {th }}$ February, 2016

\section{Correspondence to}

"E-mail: biswa.nayak@yahoo.co.in

\section{Keywords}

Growth, onion, gromorsulphur, yield, gypsum.

\begin{abstract}
A field experiment was conducted in the Regional Research Technology and Transfer Station (RRTTS), Chiplima, Sambalpur for two years to study the effect of different sources and levels on growth, yield and uptake of sulphur in onion (cv. Nasik Red). The treatment consists of two sources of sulphur (elemental gromor sulphur and gypsum) and three levels of sulphur (20,35 and $50 \mathrm{~kg} \mathrm{~S}$ ha ${ }^{-1)}$ from both the sources along with control by adopting RBD with three replications. The result showed that yield attributes like plant height, bulb length, bulb diameter, neck length and average weight of bulb were increased significantly up to $35 \mathrm{~kg} \mathrm{~S}^{-1}$ and thereafter, declined in both the sources of sulphur. The maximum bulb yield was obtained with application of sulphur at $35 \mathrm{~kg} \mathrm{ha}^{-1}$ and it was significantly superior to no sulphur and $20 \mathrm{~kg} \mathrm{~S}^{-1}$ and at par with $50 \mathrm{~kg} \mathrm{~S}^{-1}$ in both the sources of

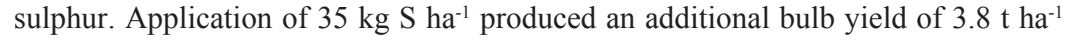
in gypsum and $5.4 \mathrm{t} \mathrm{ha}^{-1}$ in gromorsulphur over control. The sulphur use efficiency of the crop showed an increasing trend up to $35 \mathrm{~kg} \mathrm{~S} \mathrm{ha}^{-1}$ and thereafter decreased in both the sources. The highest net return and benefit cost ratio were achieved with the application of $35 \mathrm{~kg} \mathrm{~S} \mathrm{ha}^{-1}$ in both the sources of sulphur. Comparing two sulphur sources, gromorsulphur resulted in higher growth, bulb yield, sulphur use efficiency and economics in comparison to gypsum.
\end{abstract}

\section{Introduction}

Onion (Allium cepa L.) the "queen of the kitchen" belongs to family Alliaceae and widely used as an important vegetable and spice crops grown for local consumption and export. Among all spice crops, onion has great significance for its diversified use. In Odisha, onion is being cultivated in about 0.351 ha with an average productivity of $\left.12.0 \mathrm{tha}^{-1}\right)$ which is lower than the national productivity $\left(14.1 \mathrm{tha}^{-1}\right)$ (Anonymous, 2012-13). The reasons for low productivity is mainly due to inadequate supply of nutrients, particularly sulphur. Sulphur is recognized as the fourth major plant nutrient after nitrogen, phosphorus and potassium in crops. Sulphur deficiency in Indian soils adversely affect crop production even though crop is applied with recommended dose of NPK fertilizers (Kumar and Singh, 1995). Onion is a sulphur loving plant and the requirement is high for its proper growth and yield.
Sulphur is recognized as an important nutrient for higher yield and quality of onion bulbs (Thippeswamy, 1993). Pungency in onion is attributed to presence of an alkaloid "allyl propyl disulphide" in which sulphur is the prime constituent. Not only sulphur is extremely useful increasing the bulb yield of onion but also improves its quality, especially pungency and flavours (Jaggi and Dixit, 1993). Sulphur application in cropis not only importance for nutritive value and flavors but also builds resistance against pests and diseases (Bell, 1981). The yield potential of onion has not been exploited fully as the sulphur fertilizer is used in low quantity in spite of its high requirement. It is essential for building up sulphur containing amino acids (cysteine, cystine and methionine), which are building blocks for essential proteins in the plant. It is essential for good vegetative growth and bulb development in onion (Anwar et al., 2001). Gradually sulphur deficiency is becoming acute due to extensive use of sulphur free fertilizers, intensive 
crop production and inherent low status of the soil in most of the Indian soils. Non-application of sulphur in sulphur deficient soils has often resulted in low yield of onion. Sulphur deficient plants have also tendency towards the poor utilization of macro and micronutrients (Kumar and Singh,1994). Gromorsulphur is unique granular sulphur fertilizers $(90 \% \mathrm{~S}+10 \%$ bentollite clay) composed of finely divided (micronized) $\mathrm{SO}_{4}^{2-}$ sulphur particles which is readily dispersed when wetted in soil and becomes readily available to growing crops. Gypsum is available for agricultural use as source of sulphur nutrient nutrition for plants is becoming costly. Therefore, the present investigation was under taken to study effect of different sources and doses of sulphur fertilizer on growth, yield and uptake by onion (Allium cepa L.)

\section{Materials and Methods}

A field experiment was conducted on during rabi, 2012 and 2013 in the experimental plot of the Regional Research and Technology Transfer Station, Chiplima, Sambalpur, Odisha. The acidic ( $\mathrm{pH}$ 5.64) soil of the experimental field was sandy loam in texture, low in organic carbon $(0.45 \%)$ and available $\mathrm{N}, \mathrm{P}, \mathrm{K}$ and $\mathrm{S}$ content were 230, 10.3, 158 and $14.6 \mathrm{~kg} \mathrm{ha}^{-1}$, respectively. The experiment was laid out in randomized block design with 3 replications. Sulphur was applied in the form of elemental sulphur (Gromorsulphur) and gypsum. There were seven treatments including control along with three doses of sulphur i.e. 20,35 and $50 \mathrm{~kg} \mathrm{ha}^{-1}$ from both the sources. Total sulphur content in elemental gromorsulphur and gypsum was 90.0 and $16.0 \%$, respectively. A uniform recommended dose of $\mathrm{N}: \mathrm{P}_{2} \mathrm{O}_{5}: \mathrm{K}_{2} \mathrm{O}\left(120: 60: 100 \mathrm{~kg} \mathrm{ha}^{-1}\right)$ was applied to all the plots. Onion variety Nasik red was grown with different doses of sulphur as per the treatment plan and irrigation was applied through drip. Basal application was made for both the sources mixed uniformly in soil 10 days prior to transplanting, whereas full doses of $\mathrm{P}$ along with $50 \% \mathrm{~N}$ and $50 \% \mathrm{~K}$ were applied as basal to the onion crop. Rest $50 \%$ of both $\mathrm{N}$ and $\mathrm{K}$ were applied after three and six weeks after transplanting in two equal splits. The crop was transplanted $2^{\text {nd }}$ week of November with a spacing of $20 \times 10 \mathrm{~cm}^{2}$ in both the years. Plant protection measures were taken as per need of the crop. All other cultural operations were carried out as per the scientific recommendations. The crop was harvested on $2^{\text {nd }}$ week of March during the both years of study. The observations on yield and yield attributing parameters were recorded. The bulbs and stalk of onion samples were driedin oven at $65{ }^{\circ} \mathrm{C}$ and digested in diacid mixture of $\mathrm{HNO}_{3}$ and $\mathrm{HClO}_{4}$ in the ratio of $3: 1$ proportion. The $\mathrm{S}$ content in plant extract was determined turbidimetrically (Chesnin and Yen, 1951). Sulphur use efficiency (SUE) was calculated as per the formula given below:

$$
\text { Sulphur use efficiency }(\mathrm{SUE})=\frac{\mathrm{Ys}-\mathrm{Yc}}{\mathrm{S}}
$$

Where $\mathrm{Y}_{\mathrm{s}}$ refers to the bulb yield of onion $\left(\mathrm{kg} \mathrm{ha}^{-1}\right)$ in sulphur applied plot

$\mathrm{Y}_{\mathrm{c}}$ refers to the bulb yield of onion $\left(\mathrm{kg} \mathrm{ha}^{-1}\right)$ in control plot $\mathrm{S}$ is the amount of sulphur applied to a particular treatment in $\mathrm{kg} \mathrm{ha}^{-1}$.

From the pooled data, economics was worked out on the basis of prevailing market price of the produce and inputs used in the experiment. The recorded data for various parameters were statistically analyzed (Panse and Sukhatme, 1978).

\section{Results and Discussion}

\subsection{Growth and yield attributes}

Data on growth and yield attributes given in Table 1 revealed that yield attributes like plant height, bulb length, bulb diameter, neck length and average weight of bulb were increased significantly up to $35 \mathrm{~kg} \mathrm{~S} \mathrm{ha}^{-1}$ and thereafter, declined with higher dose of sulphur application $\left(50 \mathrm{~kg} \mathrm{ha}^{-1}\right)$ in both the sources. Dry weight of bulb were maximum due to application of $35 \mathrm{~kg} \mathrm{~S} \mathrm{ha}^{-1}$ which was significantly superior to no sulphur and $20 \mathrm{~kg} \mathrm{~S}^{-1}$ but statistically at par with 50 $\mathrm{kg} \mathrm{S} \mathrm{ha-1} \mathrm{in} \mathrm{both} \mathrm{the} \mathrm{sources.} \mathrm{Application} \mathrm{of} \mathrm{sulphur} \mathrm{from}$ both the sources did not affect significantly in case of neck diameter and dry weight of neck and leave. Overall increase in growth and yield attributes may be due to its role in balanced fertilization, performs many physiological functions like synthesis of sulphur containing amino acids and development of profuse root system in plants which might have resulted in an increased uptake of nutrients ultimately increasing the rate of photosynthesis. The finding was also reported by Jaggi (2004); Tripathy et al. (2013) in onion.

\subsection{Bulb yield}

The results indicated in the Table 2 showed that application of sulphur up to $35 \mathrm{~kg} \mathrm{ha}^{-1}$ from both the sources of sulphur significantly increased bulb yield of onion. Pooled value of two years data showed that the bulb yield wasdecreased at higher levels of sulphur $\left(50 \mathrm{~kg} \mathrm{ha}^{-1}\right)$ application in both the sulphur sources. Application of $35 \mathrm{~kg} \mathrm{~S} \mathrm{ha}^{-1}$ produced an additional bulb yield of $3.8 \mathrm{t} \mathrm{ha}^{-1}$ in gypsum and $5.4 \mathrm{t} \mathrm{ha}^{-1}$ in gromorsulphur over recommended dose of NPK fertilizers. Between both the sulphur sources tested, gromorsulphur resulted higher bulb yield over gypsum. This result was corroborates obtained by Singh (2008); Channagouda et al. (2009); Tripathy et al. (2013) in onion. The higher crop response with the application of gromorsulphur might be due to controlled release characteristics of micronized $\mathrm{SO}_{4}^{2-}$ sulphur particles which makes it readily available for utilization by the crop.Poor crop response with gypsum might be due to availability of less $\mathrm{SO}_{4}^{2-}$ for crop because of leaching loss in coarse textured soils. 


\begin{tabular}{|c|c|c|c|c|c|c|c|c|}
\hline Treatments & $\begin{array}{l}\text { Plant } \\
\text { height } \\
(\mathrm{cm})\end{array}$ & $\begin{array}{l}\text { Bulb } \\
\text { length } \\
(\mathrm{cm})\end{array}$ & $\begin{array}{l}\text { Bulb } \\
\text { diameter } \\
(\mathrm{cm})\end{array}$ & $\begin{array}{l}\text { Neck } \\
\text { length } \\
(\mathrm{cm})\end{array}$ & $\begin{array}{l}\text { Neck } \\
\text { diameter } \\
(\mathrm{cm})\end{array}$ & $\begin{array}{c}\text { Average } \\
\text { weight of bulb } \\
\text { (g) }\end{array}$ & $\begin{array}{l}\text { Dry weight } \\
\text { of bulb } \\
\text { (g) }\end{array}$ & $\begin{array}{c}\text { Dry weight of } \\
\text { neck+leave } \\
\text { (g) }\end{array}$ \\
\hline Control (RDF) & 56.39 & 5.93 & 5.26 & 6.10 & 0.66 & 107.82 & 11.50 & 9.70 \\
\hline $\mathrm{RDF}+\mathrm{Gy} 20 \mathrm{~kg} \mathrm{~S} \mathrm{ha}^{-1}$ & 62.19 & 6.83 & 6.38 & 6.77 & 0.83 & 127.56 & 13.28 & 11.73 \\
\hline $\mathrm{RDF}+\mathrm{Gy} 35 \mathrm{~kg} \mathrm{~S} \mathrm{ha}^{-1}$ & 68.48 & 7.65 & 7.29 & 7.36 & 1.05 & 146.58 & 16.20 & 12.23 \\
\hline $\mathrm{RDF}+\mathrm{Gy} 50 \mathrm{~kg} \mathrm{~S} \mathrm{ha}^{-1}$ & 70.15 & 7.35 & 6.87 & 7.30 & 1.08 & 136.79 & 14.12 & 12.55 \\
\hline $\mathrm{RDF}+\mathrm{Gr} 20 \mathrm{~kg} \mathrm{~S} \mathrm{ha}^{-1}$ & 64.67 & 7.29 & 6.58 & 6.58 & 0.85 & 132.67 & 14.21 & 11.27 \\
\hline $\mathrm{RDF}+\mathrm{Gr} 35 \mathrm{~kg} \mathrm{~S} \mathrm{ha}^{-1}$ & 71.11 & 8.13 & 7.40 & 7.93 & 1.21 & 152.13 & 17.27 & 12.90 \\
\hline $\mathrm{RDF}+\mathrm{Gr} 50 \mathrm{~kg} \mathrm{~S} \mathrm{ha}^{-1}$ & 73.04 & 7.94 & 7.07 & 8.10 & 1.14 & 141.67 & 16.07 & 13.03 \\
\hline $\operatorname{SEm} \pm$ & 1.37 & 0.24 & 0.28 & 0.20 & 0.22 & 6.34 & 0.94 & 0.34 \\
\hline $\mathrm{CD}(p=0.05)$ & 4.06 & 0.77 & 0.80 & 0.56 & NS & 18.21 & 2.77 & NS \\
\hline
\end{tabular}

RDF: Recommended dose of NPK fertilizers for the crop, Gy: Gypsum; Gr: Gromor sulphur-90

\begin{tabular}{|c|c|c|c|c|c|c|c|c|}
\hline Treatments & $\begin{array}{c}\text { Bulb } \\
\text { yield } \\
\left(\mathrm{t} \mathrm{ha}^{-1}\right)\end{array}$ & $\begin{array}{c}\text { Sulphur } \\
\text { use efficiency } \\
\left(\mathrm{kg} \mathrm{bulb} \mathrm{kg} \mathrm{S}^{-1}\right)\end{array}$ & $\begin{array}{l}\text { Dry matter } \\
\text { accumula- } \\
\text { tion }\left(\mathrm{t} \mathrm{ha}^{-1}\right)\end{array}$ & $\begin{array}{c}\text { Sulphur } \\
\text { content (\%) } \\
\text { (whole plant) }\end{array}$ & $\begin{array}{l}\text { Sulphur up- } \\
\text { take }\left(\mathrm{kg} \mathrm{ha}^{-1}\right) \\
\text { (whole plant) }\end{array}$ & $\begin{array}{l}\text { Gross } \\
\text { return } \\
\left(₹ \text { ha }^{-1}\right)\end{array}$ & $\begin{array}{l}\text { Net return } \\
\left(₹ \mathrm{ha}^{-1}\right)\end{array}$ & $\begin{array}{l}\mathrm{B}: \mathrm{C} \\
\text { ratio }\end{array}$ \\
\hline Control (RDF) & 18.5 & - & 10.6 & 0.25 & 26.5 & $1,85,000$ & $1,24,543$ & 3.06 \\
\hline $\mathrm{RDF}+\mathrm{Gy} 20 \mathrm{~kg} \mathrm{~S} \mathrm{ha}^{-1}$ & 20.0 & 75.0 & 12.5 & 0.33 & 41.2 & $2,00,000$ & $1,39,243$ & 3.29 \\
\hline $\mathrm{RDF}+\mathrm{Gy} 35 \mathrm{~kg} \mathrm{~S} \mathrm{ha}^{-1}$ & 22.3 & 108.6 & 14.2 & 0.39 & 52.5 & $2,23,000$ & $1,62,018$ & 3.65 \\
\hline $\mathrm{RDF}+\mathrm{Gy} 50 \mathrm{~kg} \mathrm{~S} \mathrm{ha}^{-1}$ & 22.0 & 76.0 & 13.3 & 0.38 & 50.5 & $2,20,000$ & $1,58,793$ & 3.59 \\
\hline $\mathrm{RDF}+\mathrm{Gr} 20 \mathrm{~kg} \mathrm{~S} \mathrm{ha}^{-1}$ & 20.5 & 100.0 & 12.7 & 0.36 & 45.7 & $2,05,000$ & $1,43,794$ & 3.35 \\
\hline $\mathrm{RDF}+\mathrm{Gr} 35 \mathrm{~kg} \mathrm{~S} \mathrm{ha}^{-1}$ & 23.9 & 154.3 & 15.0 & 0.42 & 63.0 & $2,39,000$ & $1,77,493$ & 3.88 \\
\hline $\mathrm{RDF}+\mathrm{Gr} 50 \mathrm{~kg} \mathrm{~S} \mathrm{ha}^{-1}$ & 23.0 & 90.0 & 14.5 & 0.45 & 66.7 & $2,30,000$ & $1,68,043$ & 3.71 \\
\hline $\operatorname{SEm} \pm$ & 0.7 & - & 0.6 & 0.02 & 2.3 & & & \\
\hline $\mathrm{CD}(p=0.05)$ & 2.0 & - & 1.8 & 0.05 & 6.7 & & & \\
\hline
\end{tabular}

RDF: Recommended dose of NPK fertilizers for the crop; Gy: Gypsum; Gr: Gromor sulphur-90

\subsection{Sulphur use efficiency (SUE)}

Sulphur use efficiency varied from 75.0 to $154.3 \mathrm{~kg}$ of bulb $\mathrm{kg}^{-1}$ of sulphur applied irrespective of different sources of sulphur. The sulphur use efficiency of the crop showed an

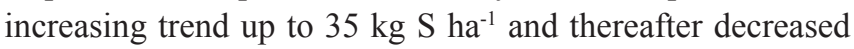
in both the sources. Between both the sulphur sources tested, gromorsulphur resulted higher sulphur use efficiency over gypsum. Application of higher dose of sulphur to the soil produce high concentration of sulphurin the solution phase at the root zone which might have reduce the sulphur use efficiency due to its antagonistic effect.

\subsection{Sulphur content and uptake}

The application of sulphur up to $35 \mathrm{~kg} \mathrm{ha}^{-1}$ from both the sources significantly increased sulphur content and its uptake by onion (Table 2). Sulphur content and its uptake were decreased non-significantly at higher levels of sulphur $(50 \mathrm{~kg}$ $\mathrm{ha}^{-1}$ ) due to application of gypsum whereas, in gromorsulphur both the parameters were increased non significantly at higher levels of sulphur $\left(50 \mathrm{~kg} \mathrm{ha}^{-1}\right)$. Between both the sulphur sources tested, gromorsulphur resulted higher sulphur content and its uptake over gypsum.

\subsection{Economics}

The highest net return and benefit-cost ratio of respectively were observed (Table 2) with application of $35 \mathrm{~kg} \mathrm{~S} \mathrm{ha}^{-1}$ followed by $50 \mathrm{~kg} \mathrm{~S} \mathrm{a}^{-1}$ and $20 \mathrm{~kg} \mathrm{~S} \mathrm{ha}{ }^{-1}$ and the lowest value was recorded for no sulphur application in both the sources of sulphur. Between both the sulphur sources tested, gromor sulphur resulted higher net return and benefit-cost ratio over gypsum.

\section{Conclusion}

Application of $35 \mathrm{~kg} \mathrm{~S} \mathrm{ha}^{-1}$ is found to be advantageous for achieving higher of bulb yield in both the forms of sulphur such as elemental gromorsulphur and gypsum. Between the 
two sources of sulphur, gromorsulphur was better than that of gypsum. Hence, gromorsulphur can be recommended as a good source of sulphur fertilizer because of its high concentration, slow release and minimum leaching loss and less requirement particularly for onion cultivation.

\section{References}

Anwar, M.N., Sarker, J.U., Rahman, M., Islam, M.A., Begum, M., 2001. Response of onion to nitrogen, phosphorus, potassium, sulphur and zinc. Bangladesh Journal of Environment Science 7, 68-72.

Annonymous., 2012-13. Odisha Agriculture Statistics. Govt of Odisha.

Channagouda, R.F., Ajjappalavara, P., Kamble, A.S., 2009. Response of onion to different levels of irrigation and sulphur in alfisoils of northen transitional tract of Karnataka. The Asian Journal of Horticulture 4(1), 152-155.

Chesnin, L., Yen, C.H., 1951. Turbidimetric determination of available sulphur. Soil Science Society of America proceeding 15, 149-151.

Jaggi, R.C., 2004. Effect of sulphur levels and sources on composition and yield of onion (Allium cepa). Indian Journal of Agricultural Science 74, 219-220.

Jaggi, R.C., Dixit, S.P., 1999. Onion responses to sulphur in representative vegetable growing soils of Kanger Valley of Himachal Pradesh. Indian Journal of Agricultural Science 69, 289-291.

Kumar, A., Singh, O., 1994. Role of sulphur in nutrient utilization and catalase activity in onion crop. Indian Journal Agricultural Research 28, 15-19.

Panse, V.G., Sukhatme, P., 1978. Statistical methods for Agricultural workers. ICAR, New Delhi.

Singh, S., 2008. Effect of sulphur on yields and S uptake by onion and garlic grown in acid Alfisol of Ranchi. Agriculture Science Digest 28, 189-191.

Tripathy, P., Sahoo, B.B., Priyadarshini, A., Das, S.K., Dash, D.K., 2013. International Journal of Bio-resource and Stress Management 4(4), 641-644. 